\title{
The Effect of Incarceration on Tuberculosis Treatment Outcomes in Brazil: a Retrospective Cohort Study
}

Jamieson O'Marr ${ }^{1}$, Crhistinne Gonçalves ${ }^{2}$, Denise Arakaki-Sanchez ${ }^{3}$, Daniele Maria Pelissari $\mathrm{PhD}^{3}$, Fernanda Dockhorn Costa ${ }^{3}$, Julio Croda ${ }^{2,4,5^{*}}$, Katharine S. Walter ${ }^{6 *}$, Jason R. Andrews ${ }^{6 *}$

1. Yale School of Medicine, New Haven, CT, USA

2. Federal University of Mato Grosso do Sul, School of Medicine, Campo Grande, MS, Brazil

3. National Tuberculosis Control Program, Brasília, DF, Brazil

4. Oswaldo Cruz Foundation, Public Health, Campo Grande, MS, Brazil

5. Department of Epidemiology of Microbial Diseases, Yale School of Public Health, New Haven, CT, USA

6. Department of Medicine, Stanford University School of Medicine, Stanford, CA, USA

*Contributed equally

Running Head: Incarceration and TB outcomes in Brazil

Article Word Count: 2491

No. of references: 27

No. of Tables: 3

No of Figures: 2

Keywords: tuberculosis; incarceration; treatment outcomes; DOTS

Correspondence:

Jamieson O'Marr

Yale School of Medicine

333 Cedar St

New Haven CT, USA, 06510

Email: jamiesonomarr@gmail.com

NOTE: This preprint reports new research that has not been certified by peer review and should not be used to guide clinical practice. 


\section{Abstract}

Background: Tuberculosis notifications in Latin American prisons have more than doubled over the past two decades; however, treatment outcomes and their determinants among incarcerated individuals in this region are not well understood.

Methods: Newly diagnosed drug-susceptible tuberculosis cases reported to Brazil's Sistema de Informação de Agravos de Notificação (SINAN) between January 2015 and December 2017 were included. Multivariate logistic regression was used to assess socioeconomic and clinical factors associated with treatment success among incarcerated individuals.

Results: Incarcerated individuals $(\mathrm{n}=17,776)$ had greater treatment success than non-incarcerated individuals $(\mathrm{n}=160,728 ; 82.2 \%$ vs $75.1 \%, \mathrm{p}<0.0001)$, including after adjusting for demographic and clinical risk factors (adjusted Odds Ratio [aOR]: 1.27; 95\% CI: 1.19-1.34). These differences were partially mediated by increased use of directly observed therapy among incarcerated individuals (DOT) (61\% vs 47\%, p $<0.001)$, which was associated with greater efficacy in the incarcerated population (aOR 2.56 vs aOR 2.17; $<<0.001$ ). DOT was associated with improved treatment success among incarcerated subpopulations at elevated risk of poor outcomes.

Conclusion: Tuberculosis treatment success among incarcerated individuals in Brazil is higher than non-incarcerated individuals, but both fall below WHO targets. Expanding the use of DOT and services for socially and medically vulnerable individuals may improve outcomes in carceral

61 settings. 


\section{Article}

\section{INTRODUCTION}

65 Tuberculosis remains one of the leading causes of death by an infectious disease. In 2019 ,

66 there were an estimated 10 million cases with approximately 1.2 million deaths among HIV-

67 negative individuals and an additional 250,000 deaths among HIV co-infected individuals ${ }^{1}$. The

68 World Health Organization (WHO) has identified 30 countries with the highest burden of

69 tuberculosis, where $87 \%$ of the world's new tuberculosis cases occurred in $2019^{1}$. Brazil remains

70 the only country within the Americas within this group.

71 The incidence of tuberculosis in Brazil has slowly declined over the last 20 years,

72 although in the last three years there has been a modest increase ${ }^{2}$. This trend has been part of a

73 troubling rise in tuberculosis cases across Central and South America in recent years ${ }^{3}$. The rate

74 of incarceration in Central and South America has increased more than $206 \%$ since 2000 while

75 tuberculosis cases among incarcerated individuals have increased by an even larger amount ${ }^{3-7}$.

76 Incarcerated individuals represent a disproportionate and growing proportion of the total

77 tuberculosis cases across Central and South America. The higher prevalence of HIV, smoking,

78 alcohol and illicit drug use among incarcerated populations, together with increased risk of

79 infection and deficiencies in health facilities, pose threats to the successful treatment of

80 tuberculosis in correctional settings ${ }^{4,8,9}$.

81 There are few published studies examining tuberculosis treatment outcomes in

82 correctional facilities in the Americas, and the factors associated with poor outcomes in these

83 settings are not well understood. Understanding these factors well and addressing them will be

84 important for controlling tuberculosis both within incarcerated populations and surrounding 
medRxiv preprint doi: https://doi.org/10.1101/2021.07.31.21261427; this version posted August 2, 2021. The copyright holder for this preprint (which was not certified by peer review) is the author/funder, who has granted medRxiv a license to display the preprint in perpetuity.

All rights reserved. No reuse allowed without permission.

85 communities. We used Brazil's national tuberculosis registry to measure the effect of

86 incarceration on tuberculosis treatment outcomes and identify risk factors for lack of tuberculosis

87 treatment success among Brazil's growing incarcerated population.

89 METHODS

90

91

92

93

94

95

96

97 therapeutic failure. isolate was resistant to isoniazid and rifampin at the time of diagnosis. Additionally, we excluded

103

104

105 cases without a reported incarceration status and limited our analysis to only new identified tuberculosis cases due to differing treatment outcome definitions among retreatment tuberculosis cases. Race is a self-reported variable within SINAN with five established survey categories:

106 black, brown or mixed race, white, Asian, and indigenous. 
medRxiv preprint doi: https://doi.org/10.1101/2021.07.31.21261427; this version posted August 2, 2021. The copyright holder for this preprint

(which was not certified by peer review) is the author/funder, who has granted medRxiv a license to display the preprint in perpetuity.

All rights reserved. No reuse allowed without permission.

Outcomes and Definitions

We defined treatment success as cases reported as "cure" in SINAN. The Brazilian

110 National Tuberculosis Program defines cure as two negative sputum smears at the end of therapy

111 or the completion of treatment with no evidence of failure and clinical and radiological criteria in

112 individuals without a sputum smear test. In our models, we defined lack of treatment success as

113 lost to follow-up, death due to tuberculosis, death due to other causes, therapeutic failure

114 (including MDR diagnosis after treatment), or transfer. We included all newly reported

115 tuberculosis cases among people above the age of 18 at diagnosis with complete information for

116 incarceration status and treatment outcome.

117 In addition to the treatment outcome, the following variables were extracted from

118 SINAN: 1) incarceration status at the time of tuberculosis notification, 2) sex, 3) age at

119 diagnosis, 4) year of diagnosis, 5) self-reported race, 6) education level, 7) received directly

120 observed therapy (at least 3 weekly assisted doses throughout the treatment course), 8) alcohol

121 use disorder, 9) HIV status, 10) diabetes status, 11) presence of a mental health condition, 12)

122 clinical form of tuberculosis 13) Brazilian state of diagnosis. The clinical variables of alcohol use

123 disorder, diabetes, and presence of a mental health condition are determined and reported by the

124 healthcare worker notifying the case to SINAN at the time of diagnosis.

\section{Statistical Analysis}

127 Data analysis was conducted in R (version 3.5.3) and R Studio (version 1.2.1335).

128 Missingness was under $10 \%$ for the majority of the variables included in our analysis and

129 covariates with missingness greater than $30 \%$ were excluded. To address missingness in 
medRxiv preprint doi: https://doi.org/10.1101/2021.07.31.21261427; this version posted August 2, 2021. The copyright holder for this preprint (which was not certified by peer review) is the author/funder, who has granted medRxiv a license to display the preprint in perpetuity.

All rights reserved. No reuse allowed without permission.

130 measured covariates, we employed multiple imputation for race, education level, directly

131 observed therapy (DOT), HIV status, alcohol use disorder, diabetes, and the presence of a mental

132 health condition using the mice package in $\mathrm{R}^{12,13}$.

133 We compared our outcomes and extracted demographic and clinical variables between

134 the non-incarcerated and incarcerated population with chi-squared statistics. We tested the effect

135 of clinical and sociodemographic variables on tuberculosis treatment outcome with mixed effects

136 multivariable logistic regression including incarceration status, DOT, sex, self-reported race, age

137 strata, year of diagnosis, education level, HIV status, alcohol use disorder, diabetes, mental

138 health condition, and form of tuberculosis with state included as a random effect. These variables

139 were selected based on previous studies and subject level knowledge of factors that affect

140 tuberculosis treatment outcomes. We included a multiplicative interaction between DOT and

141 incarceration to assess for any relationship between these two variables. Odds ratios with $95 \%$

142 confidence intervals were reported. To investigate the relationship between the predictors in the

143 above model more specifically among the incarcerated population, a multivariable logistic

144 regression was employed.

145

146 Ethics Statement

147 This study was approved by the IRB at Stanford University (Protocol \#50466) and the IRB at the 148 Universidade Federal Do Mato Grosso Do Sul (Protocol \#20531819.5.0000.0021).

\section{RESULTS}

A total of 178,504 new tuberculosis cases were reported to Brazil's national tuberculosis

152 registry between 2015 and 2017. Among those, 17,776 (9.96\%) individuals were incarcerated at 
medRxiv preprint doi: https://doi.org/10.1101/2021.07.31.21261427; this version posted August 2, 2021. The copyright holder for this preprint (which was not certified by peer review) is the author/funder, who has granted medRxiv a license to display the preprint in perpetuity.

All rights reserved. No reuse allowed without permission.

153 the time of diagnosis. The overwhelming majority of cases notified in the incarcerated

154 population occurred among men (96.4\%), compared to $66.2 \%$ of cases notified in the general

155 population $\left(\chi^{2}\right.$ test, $\left.\mathrm{p}<0.0001\right)$. The proportion of individuals with tuberculosis who were HIV

156 co-infected was lower among the incarcerated population than the general population (6.4\% vs

$15711.1 \% ; \mathrm{p}<0.0001)$, as was the percentage of patients with reported alcohol use disorder $(12.7 \%$

158 vs $18.6 \%, \mathrm{p}<0.001)$. Incarcerated individuals were younger (30.4 vs 42.7 years, $\mathrm{p}<0.0001)$ and

159 were more likely to be treated under DOT than non-incarcerated individuals (61.0\% vs $47.4 \%$,

$160 \mathrm{p}<0.0001)$

161

$135,238(75.8 \%)$ were considered to have treatment success, $18,261(10.2 \%)$ lost to

162 follow-up, 5,714 (3.2\%) died of tuberculosis, 8,175 (4.6\%) died by other causes, 9,254 (5.2\%)

163 transferred from the program, $730(0.4 \%)$ were subsequently diagnosed with drug-resistant

164 tuberculosis after a trial of therapy, 1,012(0.6\%) changed treatment regimen, and $120(0.07 \%)$

165 experienced therapeutic failure. Treatment success was higher among incarcerated individuals

166 compared with the general population $(82.2 \%$ vs $75.1 \%, \mathrm{p}<.0001)$. Notable differences in the

167 remaining treatment outcomes between the incarcerated and non-incarcerated populations was a

168 lower rate of death by tuberculosis $(0.9 \%$ vs $3.5 \%$; $<<0.0001)$, death by other causes $(1.3 \%$ vs

$1694.9 \% ; \mathrm{p}<.0001)$ and lost to follow-up (8.5\% vs 10.4\%; $<<0.0001)$.

170 In a multivariable model, incarceration at the time of tuberculosis notification was

171 associated with an increased odds of treatment success (Table 2; aOR: 1.26; 95\% CI: 1.19-1.34).

172 DOT was also strongly associated with treatment success (aOR: 2.16; 95\% CI: 2.11-2.22). We

173 also found a significant interaction between incarceration and DOT (aOR: 1.18; 95\% CI: 1.09-

174 1.28), suggesting that DOT has a greater positive impact on treatment success among the

175 incarcerated population compared to the general population. Factors that were negatively 
medRxiv preprint doi: https://doi.org/10.1101/2021.07.31.21261427; this version posted August 2, 2021. The copyright holder for this preprint (which was not certified by peer review) is the author/funder, who has granted medRxiv a license to display the preprint in perpetuity.

All rights reserved. No reuse allowed without permission.

176 associated with treatment success in the entire cohort included HIV co-infection (aOR: 0.33;

177 95\% CI: 0.32-0.34), reported alcohol use disorder (aOR: 0.55; 95\% CI: 0.54-0.57), age greater

178 than 65 years (aOR: 0.71; 95\% CI: 0.68-0.75) and self-reported non-white race (black, aOR:

179 0.80; 95\% CI 0.75-0.84; mixed race, aOR: 0.81; 95\% CI: 0.79-0.84; Asian, aOR: 0.83; 95\% CI:

$180 \quad 0.73-0.94)$.

181 In a multivariable model among only incarcerated individuals, DOT (Table 3; aOR: 2.50;

182 95\% CI: 2.31-2.71) and having completed a high school education (aOR: 1.77; 95\% CI: $1.58-$

183 1.97) were positively associated with treatment success. We additionally identified several

184 factors associated with lower treatment success within this population. These included a non-

185 white race (black, aOR: 0.83; 95\% CI: 0.72-0.94; mixed race, aOR: 0.75; 95\% CI: 0.69-0.82;

186 indigenous, aOR: 0.49; 95\% CI 0.29-0.82), HIV infection (aOR: 0.39; 95\% CI: 0.34-0.45),

187 reported alcohol use disorder (aOR: 0.63; 95\% CI: 0.57-0.70), a diagnosed mental health

188 condition (aOR: 0.60; 95\% CI: 0.46-0.80), and being over the age of 65 (aOR: 0.46; 95\% CI:

$189 \quad 0.33-0.65)$.

$190 \quad$ Using predicted probabilities from our multivariable model among incarcerated

191 individuals, we demonstrate that DOT was associated with increased treatment success across a

192 number of important predictors including age, self-reported race, sex, alcohol use disorder,

193 education level, and HIV status (Figure 1). Individuals with risk factors associated with lower

194 probability of treatment success had substantially improved outcomes when treated with DOT,

195 with most subpopulations having an estimated treatment success probability above $85 \%$. Use of

196 DOT among incarcerated populations varied substantially across Brazil, ranging from 0\% of

197 incarcerated patients uncovered by DOT in the state of Amapá $(n=47)$ to as many as $89 \%$ of

198 incarcerated patients not utilizing DOT in the state of Rondônia $(n=238)$ (Figure 2). In total, 8 
medRxiv preprint doi: https://doi.org/10.1101/2021.07.31.21261427; this version posted August 2, 2021. The copyright holder for this preprint (which was not certified by peer review) is the author/funder, who has granted medRxiv a license to display the preprint in perpetuity.

All rights reserved. No reuse allowed without permission.

199 out of Brazil's 27 states had over half of their incarcerated population not using DOT, leaving

200 the national average DOT coverage among incarcerated patients at $61 \%$. The states with the

201 largest population of incarcerated individuals not utilizing DOT during tuberculosis treatment

202 were São Paulo (n=2,589), Rio Grande do Sul (n=946), and Rio de Janeiro (n=658). 
medRxiv preprint doi: https://doi.org/10.1101/2021.07.31.21261427; this version posted August 2, 2021. The copyright holder for this preprint (which was not certified by peer review) is the author/funder, who has granted medRxiv a license to display the preprint in perpetuity.

All rights reserved. No reuse allowed without permission.

\section{DISCUSSION}

Tuberculosis notifications have been rising steeply in prisons in Latin America, largely

207 driven by increasing rates of incarceration ${ }^{3}$. However, the impact of incarceration on tuberculosis

208 treatment outcomes and risk factors for treatment failure within prisons have only begun to be

209 identified. Drawing upon Brazil's national tuberculosis notification system, we found that

210 incarceration at the time of tuberculosis diagnosis was associated with higher rates of treatment

211 success compared with the general population. Use of DOT was greater in prisons than the

212 community and was the strongest predictor of tuberculosis treatment success among incarcerated

213 individuals. However, the proportion of individuals achieving treatment success in prisons $(82 \%)$

214 and the general population (75\%) do not meet the World Health Organization's END-TB

215 Strategy 2025 target of $90 \%$ treatment success ${ }^{1}$. Among incarcerated individuals, we identified

216 several risk factors and demographic groups in whom treatment outcomes are particularly poor

217 which could inform the development of targeted services and interventions to reduce disparities

218 and improve outcomes.

Our study explored DOT and its relationship to overall treatment success, finding that

220 DOT is strongly associated with better treatment outcomes for all tuberculosis patients. Our

221 analysis also explored the interaction between DOT and incarceration status and demonstrated a

222 significant positive interaction, which underscores the particular importance of DOT for the

223 incarcerated population. Previous literature surrounding DOT has shown mixed efficacy ${ }^{13}$,

224 particularly in correctional settings, however our findings add to the work by Macedo et al. and

225 others which demonstrate a similar beneficial effect of DOT on treatment outcomes among

226 incarcerated individuals in Brazil ${ }^{14-16}$. The usage of DOT within the carceral setting poses

227 unique challenges; however, the observed ability of certain states to employ DOT among nearly 
medRxiv preprint doi: https://doi.org/10.1101/2021.07.31.21261427; this version posted August 2, 2021. The copyright holder for this preprint (which was not certified by peer review) is the author/funder, who has granted medRxiv a license to display the preprint in perpetuity.

All rights reserved. No reuse allowed without permission.

228 all incarcerated tuberculosis patients indicate that it is possible. The skills and strategies for the

229 effective employment of DOT therapy require further study as it has the potential to improve

230 population-level tuberculosis treatment outcomes within Brazilian prisons and in the general

231 population.

Our finding of increased odds of treatment success with incarceration is consistent with

233 previous studies of incarcerated individuals. These studies demonstrate that diagnosing and

234 treating tuberculosis during incarceration, and other infectious diseases such as HIV, may, in

235 some circumstances, improve treatment outcomes due to increased access to medical care during

236 incarceration amongst populations systematically excluded from care ${ }^{17,22}$. However, these studies

237 also find that transitions of care, such as the kinds that result from transfer within a penal system

238 or release, often result in poorer overall outcomes in incarcerated individuals ${ }^{17,19-22}$. Further

239 studies are needed to investigate outcomes of tuberculosis treatment among individuals who are

240 receiving therapy at the time of release from prison.

241

Previous studies have identified racial disparities in tuberculosis treatment outcomes in

242 the general population in Brazil..$^{8,23,25}$ We found that such disparities also exist among

243 incarcerated individuals. Adjusting for multiple other demographic and clinical attributes, black

244 incarcerated individuals had nearly $20 \%$ lower adjusted odds of treatment success than white

245 incarcerated individuals. Whether this disparity is due to delays in diagnoses, differences in

246 treatment or other factors is not clear from the available data, and further studies are needed to

247 understand the determinants of these disparities so that they can be effectively addressed.

248 Additional factors that were associated with worse outcomes were alcohol use disorder

249 and HIV positive status, both of which are well-documented predictors for poor treatment

250 outcomes $^{14}$. Finally, other studies have identified the importance of social, educational, and 
medRxiv preprint doi: https://doi.org/10.1101/2021.07.31.21261427; this version posted August 2, 2021. The copyright holder for this preprint (which was not certified by peer review) is the author/funder, who has granted medRxiv a license to display the preprint in perpetuity.

All rights reserved. No reuse allowed without permission.

251 economic support with improved tuberculosis treatment outcomes, something our proxy of

252 education level also supports ${ }^{17,19}$.

253 While we investigated a large, quality-controlled national tuberculosis registry, our

254 findings have several limitations. First, Brazil's tuberculosis registry had varying levels of data

255 missingness for several variables. Certain important covariates for treatment success, such as

256 smoking, were missing in more than half of notified cases and had to be excluded. For covariates

257 with less than $30 \%$ of observations missing, we used multiple imputation to handle missingness.

258 Another limitation was the lack of standardized screens for clinical covariates such as diabetes,

259 mental health disease, and alcohol use disorder. These determinations were made at the time of

260 diagnosis and thus could be susceptible to bias and underdiagnosis—potentially substantially.

261 Additionally, SINAN lacks economic indicators, limiting us to only education as a social

262 indicator. Due to significant reporting changes in the national tuberculosis registry made in 2015,

263 we could only examine cases from 2015 through 2017. While drug-resistant tuberculosis

264 epidemics in prisons have posed major challenges in many parts of the world, in Brazil, $<0.4 \%$

265 of tuberculosis cases in our study were multidrug-resistant which concurs with previous findings

266 by Macedo et al. ${ }^{14}$. Nevertheless, further studies are needed to characterize risk factors for

267 treatment success for multi-drug resistant tuberculosis in correctional settings in Brazil. Despite

268 these limitations, our study utilized a large national surveillance system that enabled a robust

269 evaluation of the covariates associated with treatment success in Brazilian prisons.

270 There is an urgent need to identify robust strategies for prompt diagnosis and effective

271 treatment to address the increasing burden of tuberculosis in prisons in Brazil and across the

272 Americas. While treatment success rates in prisons exceed those of the general population in

273 Brazil, there remains substantial room for improvement, particularly among vulnerable 
medRxiv preprint doi: https://doi.org/10.1101/2021.07.31.21261427; this version posted August 2, 2021. The copyright holder for this preprint (which was not certified by peer review) is the author/funder, who has granted medRxiv a license to display the preprint in perpetuity.

All rights reserved. No reuse allowed without permission.

274 incarcerated populations. Our findings suggest that tuberculosis treatment success can be

275 improved through expanding the use of DOT, particularly for incarcerated sub-populations at the

276 highest risk of poor outcomes.

277

278 
medRxiv preprint doi: https://doi.org/10.1101/2021.07.31.21261427; this version posted August 2, 2021. The copyright holder for this preprint (which was not certified by peer review) is the author/funder, who has granted medRxiv a license to display the preprint in perpetuity. All rights reserved. No reuse allowed without permission.

\section{References}

280 1. World Health Organization. Global Tuberculosis Report 2020. 2020.

2. World Health Organization. Tuberculosis Profile: Brazil [Internet]. Available from: https://worldhealthorg.shinyapps.io/tb_profiles/?_inputs_\&lan=\%22EN\%22\&iso2=\%22BR $\% 22 \&$ main_tabs=\%22est_tab\%22

3. Walter KS, Martinez L, Arakaki-Sanchez D, Sequera VG, Estigarribia Sanabria G, Cohen T, et al. The escalating tuberculosis crisis in central and South American prisons. The Lancet. 2021 Apr;S0140673620325782.

4. Carbone A da SS, Paião DSG, Sgarbi RVE, Lemos EF, Cazanti RF, Ota MM, et al. Active and latent tuberculosis in Brazilian correctional facilities: a cross-sectional study. BMC Infect Dis. 2015 Dec;15(1):24.

5. Bourdillon PM, Gonçalves CCM, Pelissari DM, Arakaki-Sanchez D, Ko Al, Croda J, et al. Increase in Tuberculosis Cases among Prisoners, Brazil, 2009-20141. Emerging Infectious Diseases. 2017 Mar;23(3):496-9.

6. Paião DSG, Lemos EF, Carbone A da SS, Sgarbi RVE, Junior AL, da Silva FM, et al. Impact of mass-screening on tuberculosis incidence in a prospective cohort of Brazilian prisoners. BMC Infect Dis. 2016 Dec;16(1):533.

7. Broach S, Petrone M, Ryan J, Sivram A. Reservoirs of Injustice: How incarceration for drugrelated offenses fuels the spread of tuberculosis in Brazil.

8. Basu S, Stuckler D, McKee M. Addressing Institutional Amplifiers in the Dynamics and Control of Tuberculosis Epidemics. The American Journal of Tropical Medicine and Hygiene. 2011 Jan 5;84(1):30-7.

9. Sánchez A, Huber FD, Massari V, Barreto A, Camacho LAB, Cesconi V, et al. Extensive Mycobacterium tuberculosis circulation in a highly endemic prison and the need for urgent environmental interventions. Epidemiol Infect. 2012 Oct;140(10):1853-61.

10. Brasil Ministério da Saúde. Manual de Recomendações para o Controle da Tuberculose no Brasil. 2019;366.

11. Silva GDM da, Bartholomay P, Cruz OG, Garcia LP. Avaliação da qualidade dos dados, oportunidade e aceitabilidade da vigilância da tuberculose nas microrregiões do Brasil. Ciênc saúde coletiva. 2017 Oct;22(10):3307-19. 
medRxiv preprint doi: https://doi.org/10.1101/2021.07.31.21261427; this version posted August 2, 2021. The copyright holder for this preprint (which was not certified by peer review) is the author/funder, who has granted medRxiv a license to display the preprint in perpetuity.

13. Karumbi J, Garner P. Directly observed therapy for treating tuberculosis. Cochrane Infectious Diseases Group, editor. Cochrane Database of Systematic Reviews [Internet]. 2015 May 29 [cited $2021 \mathrm{Jul} 20$ ]; Available from: https://onlinelibrary.wiley.com/doi/10.1002/14651858.CD003343.pub4

14. Macedo LR, Reis-Santos B, Riley LW, Maciel EL. Treatment outcomes of tuberculosis patients in Brazilian prisons: a polytomous regression analysis. 2013;9.

15. Macedo LR, Maciel ELN, Struchiner CJ. Factors associated with tuberculosis in persons deprived of liberty in Espírito Santo. 2020;12.

16. Prado TN do, Rajan JV, Miranda AE, Dias E dos S, Cosme LB, Possuelo LG, et al. Clinical and epidemiological characteristics associated with unfavorable tuberculosis treatment outcomes in TB-HIV co-infected patients in Brazil: a hierarchical polytomous analysis. The Brazilian Journal of Infectious Diseases. 2017 Mar;21(2):162-70.

17. Baillargeon J. Accessing Antiretroviral Therapy Following Release From Prison. JAMA. 2009 Feb 25;301(8):848.

18. Singano V, Kip E, Ching'ani W, Chiwaula L. Tuberculosis treatment outcomes among prisoners and general population in Zomba, Malawi. BMC Public Health. 2020 Dec;20(1):700.

19. Palepu A, Tyndall MW, Chan K, Wood E, Montaner JS, Hogg RS. Initiating highly active antiretroviral therapy and continuity of HIV care: the impact of incarceration and prison release on adherence and HIV treatment outcomes. :8.

20. Mabud TS, de Lourdes Delgado Alves M, Ko Al, Basu S, Walter KS, Cohen T, et al. Evaluating strategies for control of tuberculosis in prisons and prevention of spillover into communities: An observational and modeling study from Brazil. Metcalfe JZ, editor. PLoS Med. 2019 Jan 24;16(1):e1002737.

21. Schwitters A, Kaggwa M, Omiel P, Nagadya G, Kisa N, Dalal S. Tuberculosis incidence and treatment completion among Ugandan prison inmates. 2016;11.

22. Adane K. Tuberculosis treatment outcome and predictors in northern Ethiopian prisons: a five-year retrospective analysis. 2018;8.

23. Eshetie $S$, Gizachew $M$, Alebel A, van Soolingen D. Tuberculosis treatment outcomes in Ethiopia from 2003 to 2016, and impact of HIV co-infection and prior drug exposure: A systematic review and meta-analysis. Subbian S, editor. PLoS ONE. $2018 \mathrm{Mar}$ 19;13(3):e0194675.

24. Thomas BE, Thiruvengadam K, S. R, Kadam D, Ovung S, Sivakumar S, et al. Smoking, alcohol use disorder and tuberculosis treatment outcomes: A dual co-morbidity burden that cannot be ignored. Glantz SA, editor. PLoS ONE. 2019 Jul 31;14(7):e0220507. 
medRxiv preprint doi: https://doi.org/10.1101/2021.07.31.21261427; this version posted August 2, 2021. The copyright holder for this preprint

(which was not certified by peer review) is the author/funder, who has granted medRxiv a license to display the preprint in perpetuity.

All rights reserved. No reuse allowed without permission.

25. Ali MK, Karanja S, Karama M. Factors associated with tuberculosis treatment outcomes among tuberculosis patients attending tuberculosis treatment centres in 2016-2017 in Mogadishu, Somalia. 2018;14.

26. Andrade KVF de, Nery JS, Souza RA de, Pereira SM. Effects of social protection on tuberculosis treatment outcomes in low or middle-income and in high-burden countries: systematic review and meta-analysis. Cad Saúde Pública [Internet]. 2018 Feb 5 [cited 2020 Dec 14];34(1). Available from: http://www.scielo.br/scielo.php?script=sci_arttext\&pid=S0102$311 X 2018000102001 \&$ lng=en\&tlng=en

27. Durovni B, Saraceni V, Puppin MS, Tassinari W, Cruz OG, Cavalcante S, et al. The impact of the Brazilian Family Health Strategy and the conditional cash transfer on tuberculosis treatment outcomes in Rio de Janeiro: an individual-level analysis of secondary data. 
363 Table 1. Sociodemographic and clinical characteristics of new Brazilian TB patients from 20153642017 after imputation, by incarceration status.

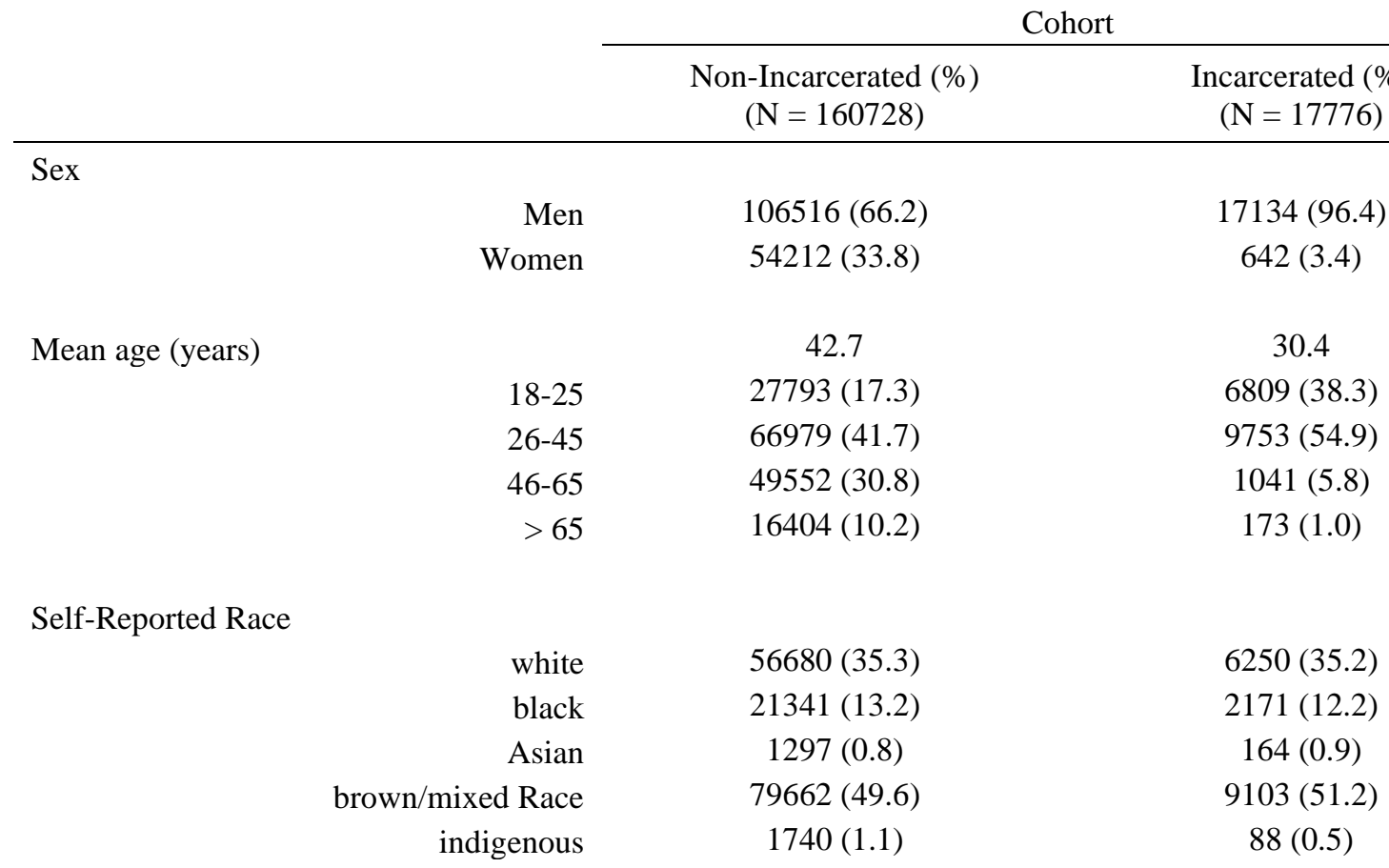

Education (years)

$48222(30.0)$

Less than 5th Grade

5th - 8th Completed

Greater than 8th Completed

Directly Observed Therapy

Comorbidities

$$
\begin{array}{r}
\text { Alcohol Use Disorder } \\
\text { HIV Positive } \\
\text { Diabetes } \\
\text { Mental Health Condition }
\end{array}
$$

Tuberculosis Form

Pulmonary

Extrapulmonary

Extrapulmonary and Pulmonary

Treatment Outcome

$$
\text { Cure }
$$

Lost to Follow-up

Death by TB

Death by Other Cause

Transfer

MDR-TB

Change in Treatment regimen

Therapeutic Failure
$49177(30.5)$

63318 (39.5)

$76124(47.4)$

$$
\begin{gathered}
29836(18.6) \\
17918(11.1) \\
14838(9.2) \\
4141(2.6)
\end{gathered}
$$

132705 (82.6)

22834 (14.2)

$5189(3.2)$

$120632(75.1)$

16748 (10.4)

$5553(3.5)$

7946 (4.9)

8045 (5.0)

$661(0.4)$

$986(0.6)$

$117(0.1)$
4439 (25.0)

8400 (47.3)

4937 (27.7)

10844 (61.0)

$<.001$

2265 (12.7)

$<.001$

1145 (6.4)

$<.001$

304 (1.7)

$<.001$

276 (1.5)

$<.001$

$<.001$

16921 (95.1)

667 (3.8)

188 (1.1)

$14606(82.2)$

1513 (8.5)

$161(0.9)$

229 (1.3)

1169 (6.6)

$69(0.4)$

$26(0.1)$

$3(0.02)$ 
medRxiv preprint doi: https://doi.org/10.1101/2021.07.31.21261427; this version posted August 2, 2021. The copyright holder for this preprint (which was not certified by peer review) is the author/funder, who has granted medRxiv a license to display the preprint in perpetuity.

All rights reserved. No reuse allowed without permission.

365 Table 2. Adjusted odds ratios for treatment success among all newly diagnosed tuberculosis 366 cases using mixed-effects multivariable regression.

\begin{tabular}{|c|c|c|}
\hline & $\mathrm{aOR}^{1}$ & $95 \% \mathrm{CI}$ \\
\hline Incarceration & 1.27 & $1.19-1.34$ \\
\hline Directly Observed Therapy (DOT) & 2.17 & $2.11-2.22$ \\
\hline Incarceration* $\mathrm{DOT}^{2}$ & 1.18 & $1.08-1.28$ \\
\hline Male sex & 0.83 & $0.81-0.85$ \\
\hline \multicolumn{3}{|l|}{ Age, years } \\
\hline $18-25$ & Ref & Ref \\
\hline $26-45$ & 1.12 & $1.08-1.16$ \\
\hline $46-65$ & 1.19 & $1.15-1.24$ \\
\hline$>65$ & 0.71 & $0.68-0.75$ \\
\hline
\end{tabular}

Self-Identified Race

Education

$\begin{array}{rcc}\text { white } & \text { Ref } & \text { Ref } \\ \text { black } & 0.80 & 0.75-0.84 \\ \text { Asian } & 0.83 & 0.73-0.94 \\ \text { brown/mixed Race } & 0.81 & 0.79-0.84 \\ \text { indigenous } & 0.96 & 0.85-1.09\end{array}$

Less than 5th Grade

Ref

Ref

5th - 8th Completed

1.04

$1.01-1.07$

Greater than 8th Completed

1.57

$1.53-1.62$

Year of Diagnosis

$\begin{array}{lcc}2015 & \text { Ref } & \text { Ref } \\ 2016 & 1.03 & 1.00-1.06 \\ 2017 & 0.95 & 0.93-0.98\end{array}$

Comorbidities

$\begin{array}{rll}\text { HIV Positive } & 0.33 & 0.32-0.34 \\ \text { Alcohol Use Disorder } & 0.55 & 0.54-0.57 \\ \text { Diabetes } & 1.04 & 1.00-1.08 \\ \text { Mental Health Condition } & 0.73 & 0.69-0.78\end{array}$

Tuberculosis Form

$\begin{array}{rcc}\text { Pulmonary } & \text { Ref } & \text { Ref } \\ \text { Extrapulmonary } & 1.06 & 1.02-1.09 \\ \text { ry and Pulmonary } & 0.79 & 0.74-0.84\end{array}$

${ }^{1} \mathrm{aOR}=$ Adjusted odds ratio

${ }^{2}$ Incarceration*DOT indicates the use of an interaction term 
Table 3. Factors associated with treatment success among incarcerated individuals in a multivariable logistic regression model

\begin{tabular}{lccc} 
& & $\mathrm{aOR}^{1}$ & $95 \%$ CI \\
\hline Directly Observed Therapy & & 2.50 & $2.31-2.71$ \\
Male sex & & 1.23 & $1.01-1.49$ \\
Age, years & $18-25$ & Ref & Ref \\
& $26-45$ & 1.10 & $1.01-1.19$ \\
& $46-65$ & 0.97 & $0.81-1.14$ \\
& $>65$ & 0.46 & $0.33-0.65$
\end{tabular}

Self-Identified Race

Education

$\begin{array}{rcc}\text { white } & \text { Ref } & \text { Ref } \\ \text { black } & 0.83 & 0.72-0.94 \\ \text { Asian } & 0.69 & 0.45-1.05 \\ \text { brown/mixed Race } & 0.75 & 0.69-0.82 \\ \text { indigenous } & 0.49 & 0.29-0.82\end{array}$

Less than 5th Grade 5th - 8th Completed Greater than 8th Completed

Year of Diagnosis

2015
2016
2017

Comorbidities
Ref

1.31

1.77

Ref

1.06

1.02

0.39

0.63

0.97

0.60
Ref

$1.20-1.44$

$1.58-1.97$

Ref

$0.96-1.18$

$0.93-1.13$

Mental Health Condition

Tuberculosis Form

$\begin{array}{rcc}\text { Pulmonary } & \text { Ref } & \text { Ref } \\ \text { Extrapulmonary } & 0.80 & 0.66-0.97 \\ \text { and Pulmonary } & 0.58 & 0.42-0.80\end{array}$

$0.34-0.45$

$0.57-0.70$

$0.72-1.30$

$0.46-0.80$

${ }^{1} \mathrm{aOR}=$ adjusted odds ratio 
medRxiv preprint doi: https://doi.org/10.1101/2021.07.31.21261427; this version posted August 2, 2021. The copyright holder for this preprint (which was not certified by peer review) is the author/funder, who has granted medRxiv a license to display the preprint in perpetuity.

All rights reserved. No reuse allowed without permission.

Figure Legends:

Figure 1. Predicted Probabilities of Treatment Success Among Incarcerated Individuals from the Incarcerated Multivariable Model Stratified by DOT Status. Facets indicate risk factors, points indicate mean predicted probability of treatment success, whiskers indicate interquartile ranges, and color indicates DOT treatment status. 2015 to 2017. Darker colors indicate an increasing percentage of incarcerated tuberculosis patients without DOT. 
medRxiv preprint doi: https://doi.org/10.1101/2021.07.31.21261427; this version posted August 2, 2021. The copyright holder for this preprint (which was not certified by peer review) is the author/funder, who has granted medRxiv a license to display the preprint in perpetuity.

All rights reserved. No reuse allowed without permission.

\section{Figure 1}

385
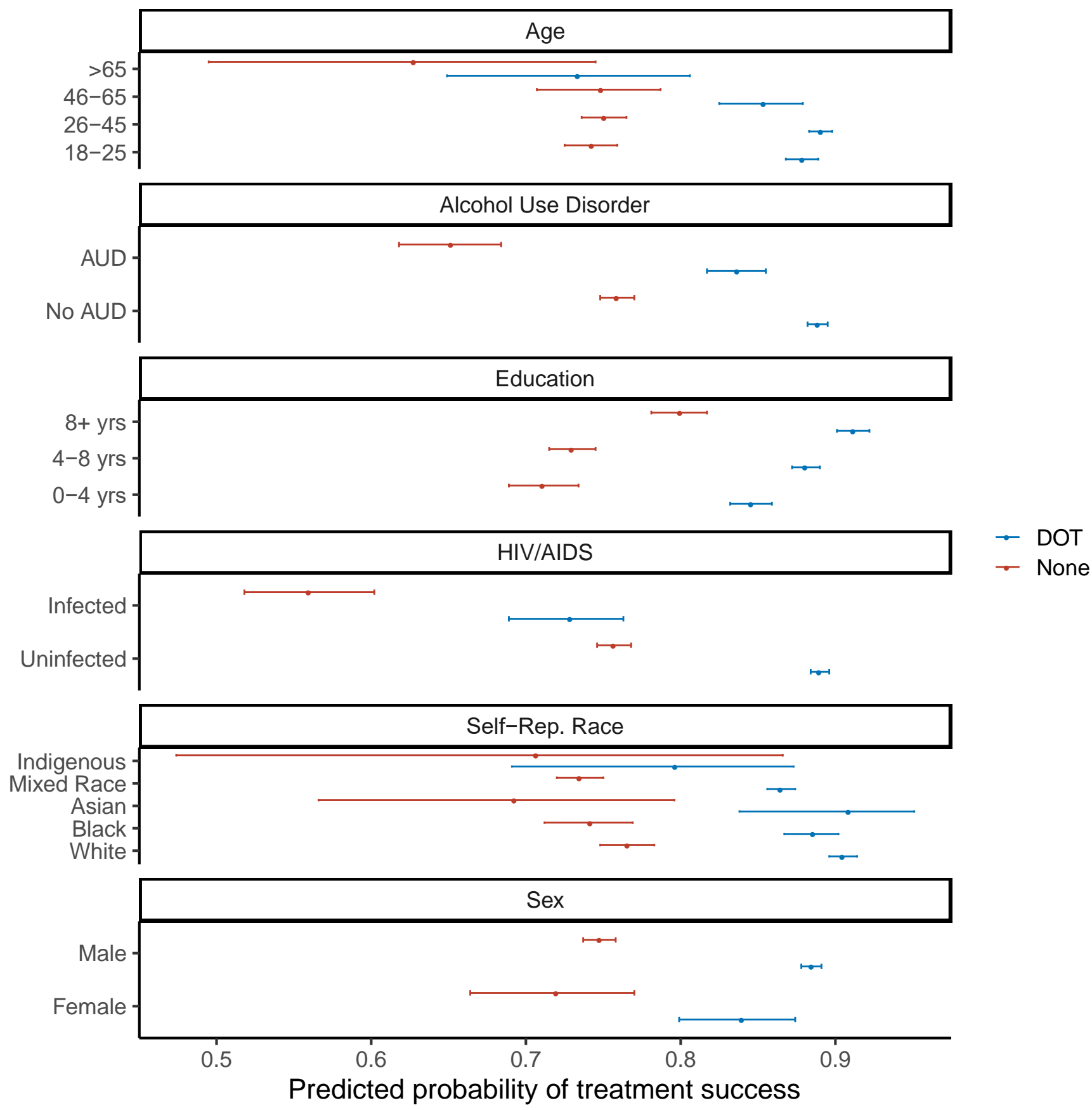
medRxiv preprint doi: https://doi.org/10.1101/2021.07.31.21261427; this version posted August 2, 2021. The copyright holder for this preprint (which was not certified by peer review) is the author/funder, who has granted medRxiv a license to display the preprint in perpetuity.

All rights reserved. No reuse allowed without permission.

Figure 2

390

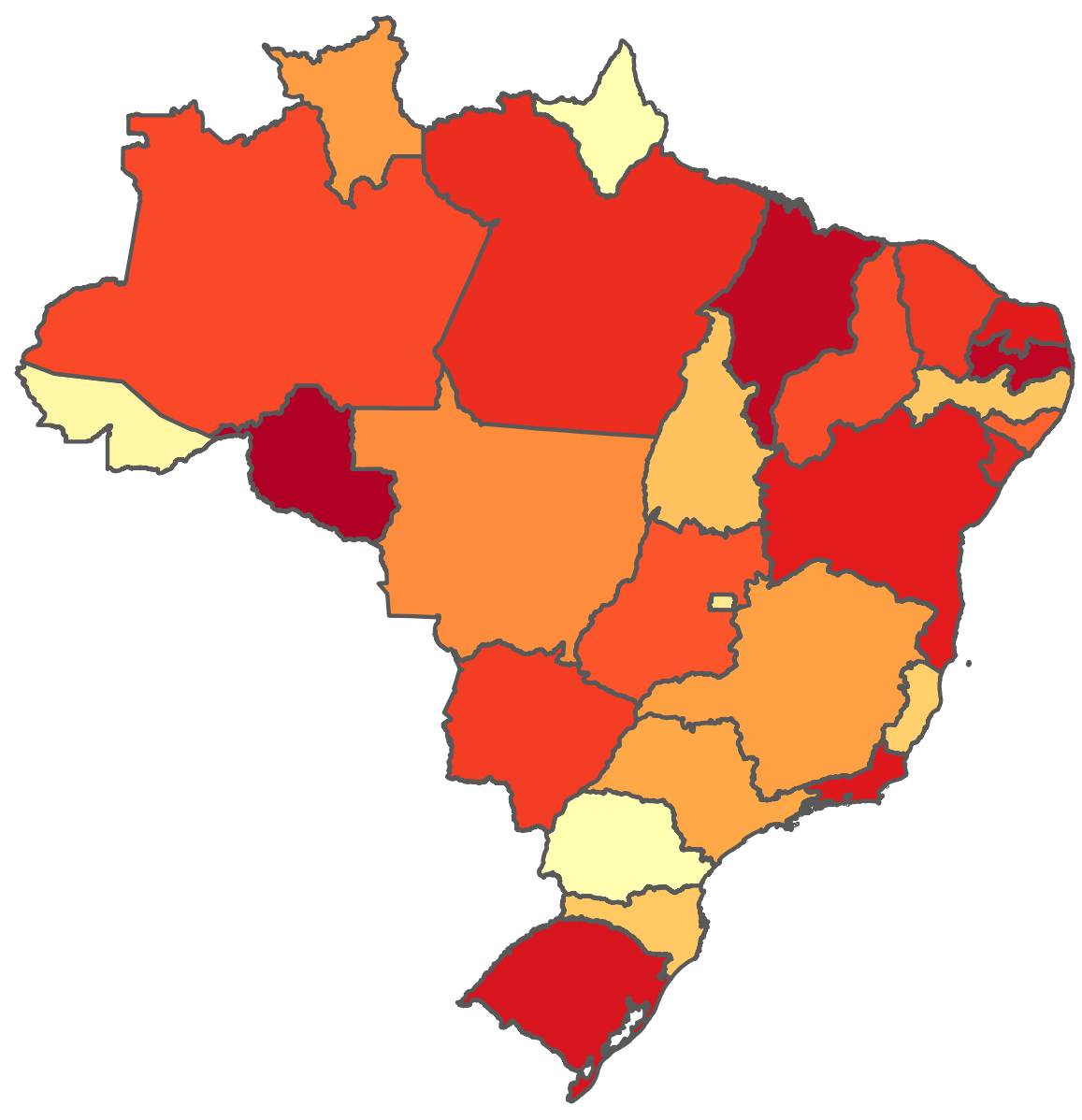

Incarcerated pop. without DOT (\%) 